\title{
A species difference between hamster and rat in the effect of oestrogens on growth of large preantral follicles*
}

\author{
I. Kim, Chandrima Shaha and G. S. Greenwald \\ Department of Physiology, Ralph L. Smith Research Center, Kansas City, Kansas 66103, U.S.A.
}

\begin{abstract}
Summary. Intact or hypophysectomized 23-day-old hamsters and rats were injected s.c. with $2 \mathrm{mg}$ diethylstilboestrol (DES) or $1 \mathrm{mg}$ oestradiol cyclopentylpropionate (OECP) on Days 23-25 and killed on Day 26. Although serum oestradiol was elevated to the same high levels by OECP, ovarian and uterine weights were increased in the rat by OECP or DES whereas only the uterus responded in the hamster. This correlated with the ability of the oestrogens to increase significantly the number of large preantral and antral follicles in the intact rat but only the number of follicles with 2-3 layers of granulosa cells in the immature hamster. Qualitative study revealed that DES and OECP increased the number of large preantral follicles in the adult hypophysectomized rat but were ineffective in the adult hamster. It is concluded that for the immature and adult hamster oestrogens do not play a major role in the recruitment of large preantral follicles.
\end{abstract}

\section{Introduction}

Williams (1940) and Pencharz (1940) were the first to show that diethylstilboestrol (DES) maintained ovarian weight in the hypophysectomized immature rat and that the response to gonadotrophins was greatly enhanced by the oestrogen treatment. Pencharz (1940) noted that the ovaries of the DES-treated animals were packed with large numbers of medium-sized follicles. Subsequently, Bradbury (1961) found that crystalline oestradiol or DES applied to one ovary of intact or hypophysectomized immature rats led to unilateral enlargement of the treated ovary and a greater responsiveness to exogenous gonadotrophins.

It has been reaffirmed that oestrogens stimulate the proliferation of granulosa cells in hypophysectomized immature rats (Goldenberg, Vaitukaitis \& Ross, 1972; Richards, 1975; Rao, Midgley \& Richards, 1978; Nakayama, Nakano \& Iwao, 1981 [consult the last article for other references]). It seems likely, therefore, that oestrogens may increase the response of granulosa cells to gonadotrophins around the time of puberty.

Similar detailed studies for other species are lacking. In hypophysectomized adult hamsters, a long-acting esterified oestrogen, oestradiol cyclopentylpropionate, in a dose of $50 \mu \mathrm{g}$ (alone or in conjunction with FSH) failed to increase the number of preantral follicles (Moore \& Greenwald, 1974). It was concluded that larger amounts of this oestrogen might be needed to stimulate proliferation of granulosa cells in the hamster ovary. A subsequent study, also using long-term hypophysectomized adult hamsters, showed that daily administration of $10 \mu \mathrm{g}$ oestradiol benzoate for 3 days increased the population of preantral follicles with 2-3layers of granulosa cells. When this treatment was followed by $100 \mu \mathrm{g} \mathrm{FSH,} 12 \mathrm{~h}$ later there was an average per ovary of 2.3 large

\footnotetext{
* Reprint requests to Dr G. S. Greenwald.
} 
preantral follicles with 8 or more layers of granulosa cells and this was the only treatment group in which follicles this size were encountered (Chiras \& Greenwald, 1978). This is a very minor response compared to the dramatic effects elicited by oestrogen in the rat.

The purpose of the present study was therefore to investigate the role of oestrogens in follicular growth in the hypophysectomized immature and adult hamster, using doses comparable to those that are effective in the rat in initiating massive development of large, healthy preantral follicles.

\section{Materials and Methods}

Experiments with immature animals. Golden hamsters and rats (Holtzman strain) were obtained from Sasco Labs (Omaha, NE) when they were 22 days old (day of birth = Day 1). Animals were hypophysectomized on Day 23 and treatment was begun on Day 23. Intact or hypophysectomized hamsters and rats were injected s.c. with oestradiol cyclopentylpropionate (OECP: Upjohn, Kalamazoo, MI) or diethylstilboestrol (DES: Sigma, St Louis, MO) in 0.1 ml sesame oil or the vehicle alone as a control. The OECP was given either as a single $1 \mathrm{mg}$ dose on Day 23 or as $1 \mathrm{mg}$ daily dose on Days 23, 24 and 25. The DES was injected s.c. at a dose of $2 \mathrm{mg} /$ animal on Days 23, 24 and 25. All animals were decapitated at $09: 00 \mathrm{~h}$ on Day 26 and trunk blood was saved for measurement of serum oestradiol. The sella turcica was examined with a dissecting microscope and animals with remnants of pituitary were discarded. The ovaries and uteri were weighed to the nearest $0 \cdot 1$ $\mathrm{mg}$ and weights were expressed as actual or relative (per $100 \mathrm{~g}$ body weight). There were 8 animals in each treatment group and one ovary was saved for histology from 6 of the animals of each group.

Experiments with adult animals. A preliminary experiment involved adult rats (180-200 $\mathrm{g}$ body weight) which were hypophysectomized at $09: 00 \mathrm{~h}$ on Day 1 of the cycle (=oestrus) and injected s.c. daily on Days, 1,2 and 3 with $2 \mathrm{mg} \mathrm{DES}(\mathrm{N}=2)$ or $1 \mathrm{mg}$ OECP on Day $1(\mathrm{~N}=3)$; the rats were killed on Day 4, ovaries and uteri weighed and one ovary saved from each animal for histology.

A more extensive experiment utilized adult hamsters $(90-110 \mathrm{~g})$ hypophysectomized and injected s.c. with various doses of OECP on Day 1 of the cycle. All animals were killed on Day 4, ovaries and uteri weighed and serum saved for measurement of oestradiol concentrations. In another experiment, hamsters were hypophysectomized on Day 1 of the cycle and $100 \mu \mathrm{g}$ OECP were introduced into the bursa of the left ovary (via a 26-gauge hypodermic needle) on Day 1 of the cycle while the contralateral ovary was similarly treated with sesame oil (5 animals). The experiment was terminated on Day 4. In the final experiment, to determine whether oestrogen would be more effective in the long-term hypophysectomized hamster (when the possibility of luteal production of progesterone was no longer a factor), adult animals were hypophysectomized on Day 1 of the cycle $(N=5)$ and $1 \mathrm{rng}$ OECP was injected on Day 8 and the animals killed $72 \mathrm{~h}$ later. Other hamsters were hypophysectomized on Day 1, injected immediately with $5 \mu \mathrm{g}$ OECP, followed on Day 8 by $1 \mathrm{mg}$ OECP; the animals were killed $72 \mathrm{~h}$ later.

Radioimmunoassay. The protocol for the radioimmunoassay of oestradiol was as described previously (Terranova \& Greenwald, 1978). Serum samples were extracted with $2 \mathrm{ml}$ diethyl ether and the antibody used was that of Exley, Johnson \& Dean (1971). The recovery of oestradiol was $90-95 \%$. The inter- and intra-assay coefficients of variation were $3.6 \%$ and $4 \cdot 2 \%$, respectively and the lower limit of the assay was $2 \mathrm{pg} /$ tube. The cross reactivity of DES with oestradiol was negligible: $0 \cdot 002 \%$.

Histology. Tissues were fixed in Bouin's fluid, processed and embedded in paraffin wax. Sections were cut at $7 \mu \mathrm{m}$ and stained with haematoxylin and eosin. All healthy follicles were counted (at $\times 100$ magnification) in every section and classified according to the scheme proposed by Greenwald (1974) in which follicles were placed in 6 categories: Stage I: preantral follicles with 2-3 layers of granulosa cells; Stage II: preantral follicles with 4-5 layers of granulosa cells; Stage $I I I$ : preantral follicles with 6-7 layers of granulosa cells; Stage $I V$ : follicles with 8 or more layers of granulosa cells; Stage $V$ : follicles with early formation of the antral cavity as a series of isolated lacunae; Stage VI: antral follicles with a single, continuous antral cavity. 


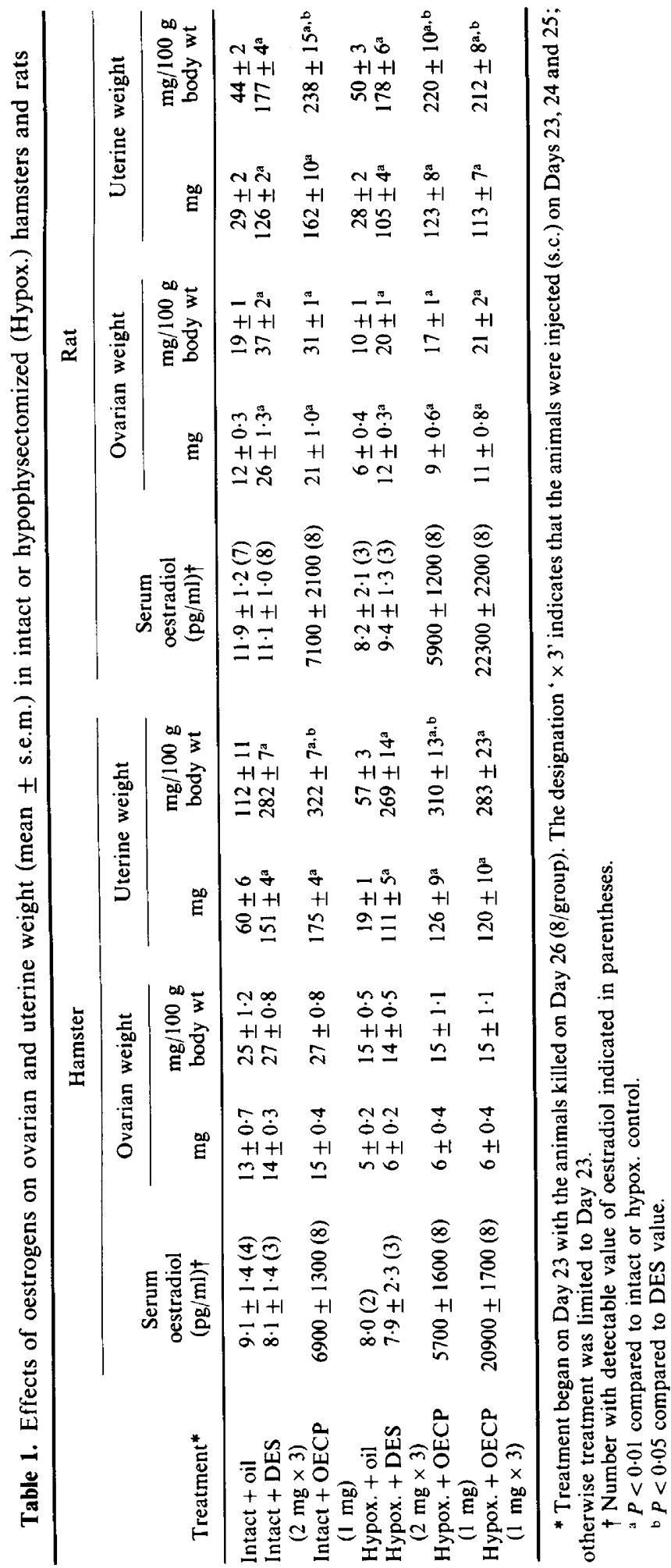


Statistics. The number of follicles and ovarian and uterine weight in intact and hypophysectomized animals were analysed by two way analysis of variance (Dixon, 1981). Comparison between results for hamsters and rats was by Student's $t$ test. Statistical significance was determined at the level of $P<0.05$.

\section{Results}

Ovarian and uterine weight in immature hamster and rat

Oestrogen treatment increased uterine weight, whether expressed as actual or relative, in intact and hypophysectomized hamsters and rats, with OECP being more effective than DES (Table 1). At Day 26, uterine weight was heavier in the intact hamster than in the rat and after hypophysectomy the decline in uterine weight was much more drastic in hamsters than rats. However, ovarian weight was significantly increased in intact and hypophysectomized rats by DES or OECP but not in hamsters.

Serum oestradiol was barely detectable in intact hamsters and rats at 26 days of age (Table 1). As to be expected, because of the lack of cross-reactivity of DES, serum oestradiol was unchanged after administration of diethylstilboestrol. Injection of OECP led to enormous increases in serum oestradiol values, especially when the hormone was administered on a daily basis, and concentrations were increased to the same extent in hamsters and rats.

Follicular distribution in the ovaries of immature hamsters and rats after oestrogen treatment

Although the total number of healthy follicles did not differ on Day 26 in the intact hamster and rat, the distribution was entirely different (Table 2). The population in the hamster ovary was

Table 2. Follicular distribution in intact and hypophysectomized (Hypox.) hamsters and rats

\begin{tabular}{|c|c|c|c|c|c|c|c|}
\hline \multirow[b]{2}{*}{ Treatment } & \multicolumn{7}{|c|}{ No. of follicles/ovary } \\
\hline & Stage I & Stage II & Stage III & Stage IV & Stage V & Stage VI & Total \\
\hline \multicolumn{8}{|l|}{ Hamster } \\
\hline Intact + oil & $232 \pm 15$ & $127 \pm 8$ & $30 \pm 2$ & $10 \pm 2$ & $3 \cdot 2 \pm 0 \cdot 6(5)$ & $3 \cdot 2 \pm 0 \cdot 8(5)$ & $405 \pm 23$ \\
\hline $\begin{array}{c}\text { Intact }+ \text { DES } \\
(2 \mathrm{mg} \times 3)\end{array}$ & $317 \pm 18^{a}$ & $113 \pm 5$ & $13 \pm 2^{\mathrm{a}}$ & $6 \pm 1$ & $1 \cdot 7 \pm 0 \cdot 3(3)$ & $1 \cdot 4 \pm 0 \cdot 2(5)$ & $451 \pm 20$ \\
\hline $\begin{array}{l}\text { Intact + OECP } \\
(1 \mathrm{mg})\end{array}$ & $303 \pm 13^{a}$ & $142 \pm 7^{b}$ & $20 \pm 1^{\mathrm{a}}$ & $10 \pm 1^{b}$ & $4 \cdot 5 \pm 0 \cdot 6$ & $1 \cdot 3 \pm 0 \cdot 3(5)$ & $481 \pm 20^{\mathrm{a}}$ \\
\hline Hypox. + oil & $176 \pm 14$ & $64 \pm 8$ & $9 \pm 1$ & $2 \cdot 2 \pm 0 \cdot 6(5)$ & 0 & 0 & $251 \pm 17$ \\
\hline $\begin{array}{c}\text { Hypox. + DES } \\
(2 \mathrm{mg} \times 3)\end{array}$ & $249 \pm 17^{3}$ & $84 \pm 7^{a}$ & $5 \pm 1$ & $\overline{1.5}(2)$ & 0 & 0 & $338 \pm 23^{a}$ \\
\hline $\begin{array}{l}\text { Hypox. + OECP } \\
\text { (1 mg) }\end{array}$ & $246 \pm 18^{a}$ & $97 \pm 8^{a}$ & $8 \pm 1$ & $2 \cdot 7 \pm 0.3(3)$ & 0 & 0 & $352 \pm 22^{a}$ \\
\hline $\begin{array}{c}\text { Hypox. }+ \text { OECP } \\
(1 \mathrm{mg} \times 3)\end{array}$ & $281 \pm 21^{a}$ & $96 \pm 8^{a}$ & $9 \pm 2$ & $2 \cdot 0 \pm 0 \cdot 6(3)$ & 0 & 0 & $386 \pm 28^{a}$ \\
\hline \multicolumn{8}{|l|}{ Rat } \\
\hline Intact + oil & $175 \pm 22$ & $95 \pm 11$ & $30 \pm 3$ & $11 \pm 2$ & $13 \pm 1$ & $39 \pm 3$ & $361 \pm 38$ \\
\hline $\begin{array}{c}\text { Intact + DES } \\
(2 \mathrm{mg} \times 3)\end{array}$ & $186 \pm 16$ & $82 \pm 8$ & $44 \pm 6^{a}$ & $27 \pm 4^{a}$ & $23 \pm 5^{a}$ & $77 \pm 7^{a}$ & $438 \pm 38$ \\
\hline $\begin{array}{l}\text { Intact + OECP } \\
(1 \mathrm{mg})\end{array}$ & $186 \pm 15$ & $105 \pm 16$ & $27 \pm 3$ & $16 \pm 2$ & $14 \pm 2$ & $58 \pm 5^{a, b}$ & $405 \pm 33$ \\
\hline Hypox. + oil & $107 \pm 12$ & $54 \pm 9$ & $14 \pm 2$ & $8 \pm 1$ & $7 \pm 1$ & $4 \cdot 5 \pm 1 \cdot 2(4)$ & $194 \pm 21$ \\
\hline $\begin{array}{l}\text { Hypox. + DES } \\
(2 \mathrm{mg} \times 3)\end{array}$ & $234 \pm 16^{\mathrm{a}}$ & $97 \pm 8^{a}$ & $50 \pm 5^{a}$ & $46 \pm 2^{\mathrm{a}}$ & $9 \pm 1$ & $5 \cdot 2 \pm 0 \cdot 9$ & $441 \pm 29^{\mathrm{a}}$ \\
\hline $\begin{array}{l}\text { Hypox. + OECP } \\
\quad(1 \mathrm{mg})\end{array}$ & $151 \pm 10$ & $64 \pm 7$ & $21 \pm 3$ & $25 \pm 6^{a}$ & $10 \pm 3$ & $5 \cdot 5 \pm 1 \cdot 7$ & $277 \pm 29$ \\
\hline $\begin{array}{c}\text { Hypox. + OECP } \\
(1 \mathrm{mg} \times 3)\end{array}$ & $218 \pm 11^{a}$ & $94 \pm 8^{3}$ & $43 \pm 3^{a}$ & $26 \pm 1^{a}$ & $10 \pm 1$ & $15 \pm 2^{a}$ & $405 \pm 16^{a}$ \\
\hline
\end{tabular}

${ }^{b} P<0.05$ compared to DES value. 
skewed towards small follicles with 2-5 layers of granulosa cells (Stages I and II) and there were only a few antral follicles (Stage VI). In comparison, the rat ovary contained many more large preantral follicles (Stage V) and abundant antral follicles (Stage VI). After injection of intact hamsters with DES or OECP, the number of Stage I follicles (2-3 layers of granulosa cells) was consistently increased. In rats, DES increased the number of Stage III-VI follicles, especially Stages V and VI; OECP increased the number of antral follicles but not to the same extent as DES. For both species, hypophysectomy resulted in a significant decline in the number of follicles in all categories. In hypophysectomized hamsters, DES or OECP significantly increased the number of small follicles but were ineffective in restoring the number of Stage V and VI follicles to the values in intact animals. In hypophysectomized rats, however, both oestrogens profoundly affected the follicular population, especially increasing the number of large preantral follicles (Stage IV). Incipient (Stage V) and antral follicles still persisted in the ovaries of the hypophysectomized rats but their numbers were unchanged after DES treatment or a single injection of OECP. However, daily treatment with OECP did increase the number of Stage VI follicles.

\section{Follicular development in the ovaries of adult hypophysectomized rat and hamster}

Treatment of hypophysectomized rats with DES or OECP increased the number of large preantral follicles (Stage IV) although these were not conspicuous because of the persistence of

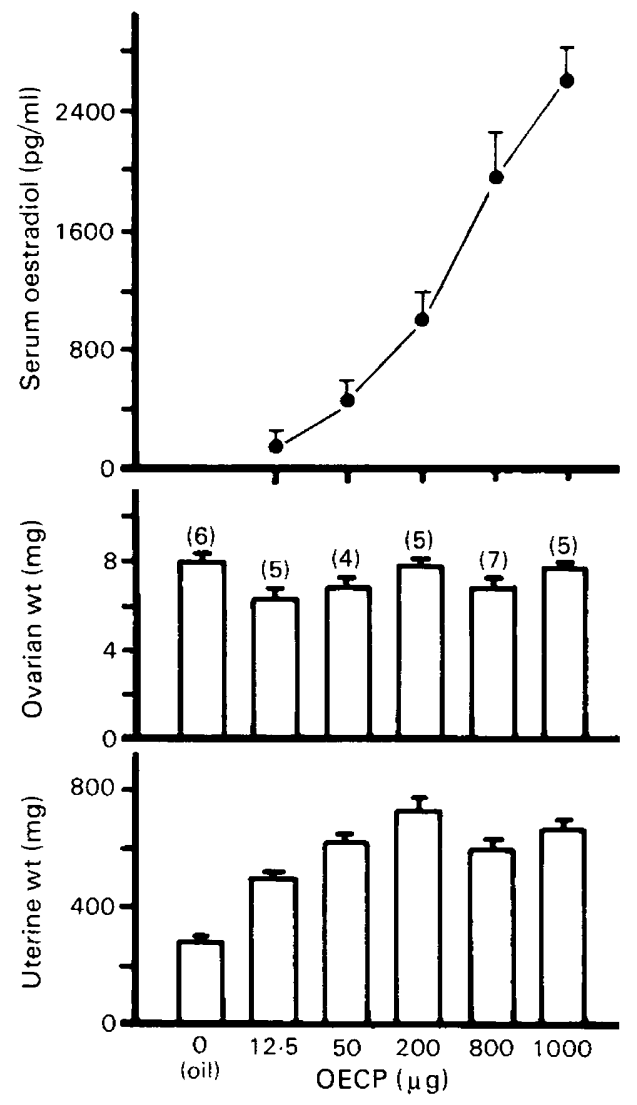

Text-fig. 1. Uterine and ovarian weight (mean + s.e.m.) and serum concentrations of oestradiol (mean \pm s.e.m.) in hamsters after s.c. injection of different amounts of oestradiol cyclopentylpropionate (OECP) on the morning of Day 1 of the cycle after hypophysectomy. The animals were killed on Day 4 . The numbers in parentheses above the ovarian weights indicate number of animals in each group. 
several generations of large corpora lutea. After hypophysectomy, the uterus weighed 1985 and 900 $\mathrm{mg}$ in the DES-treated rats and $2429 \pm 546 \mathrm{mg}$ after OECP treatment. In contrast, ovarian histology of hypophysectomized adult hamsters revealed no increase in the number of follicles at Stages III-VI and this was reflected in the fact that there was no increase in ovarian weight over the range of 0 to $1 \mathrm{mg} \mathrm{OECP}$, although uterine weight was increased by as little as $12.5 \mu \mathrm{g} \mathrm{OECP} \mathrm{(Text-}$ fig. 1). At the time of death, serum oestradiol concentrations were as high as $2600 \mathrm{pg} / \mathrm{ml}$ in hamsters injected with $1 \mathrm{mg}$ OECP (Text-fig. 1). In intact adult hamsters on Day 4 of the cycle ovarian weight is $23 \pm 3 \mathrm{mg}$ (Lukaszewska \& Greenwald, 1970) and serum oestradiol is $93 \pm 10 \mathrm{pg} / \mathrm{ml}$ (Saidapur \& Greenwald, 1978).

When applied locally to one hamster ovary after hypophysectomy on Day $1,100 \mu \mathrm{g}$ OECP failed to stimulate the ovary differentially. By Day 4 the treated ovary weighed $6.7 \pm 0.1 \mathrm{mg}$ compared to $6 \cdot 5 \pm 0 \cdot 1 \mathrm{mg}$ for the contralateral ovary. The uterus weighed $610 \pm 26 \mathrm{mg}$ and serum oestradiol was $464 \pm 97 \mathrm{pg} / \mathrm{ml}$.

In the final experiment, the injection of OECP was deferred until 8 days after hypophysectomy and the hamsters killed 3 days later. Injection of $1 \mathrm{mg}$ OECP on Day 8 resulted in small ovaries weighing $4.9 \pm 0.3 \mathrm{mg}$ and a diminished uterine response $(294 \pm 6.4 \mathrm{mg}, 5$ animals $)$. When $5 \mu \mathrm{g}$ OECP were injected on Day 1 followed by $1 \mathrm{mg}$ on Day 8 , the ovaries weighed $4.2 \pm 0.2 \mathrm{mg}$ compared to 5-7 $\mathrm{mg}$ in untreated hamsters (Moore \& Greenwald, 1974) but the uterus was considerably larger than in the previous group $(418 \pm 13.9 \mathrm{mg})$. Therefore, oestrogen priming enhanced the uterine response to a second injection of oestrogen but did not alter the refractoriness of the ovary.

\section{Discussion}

This study shows that oestrogens, unlike their effect in rats, do not influence follicular growth or ovarian weight of hypophysectomized prepubertal and adult hamsters. The initial studies with rats (Pencharz, 1940; Williams, 1940) employed subcutaneous implants of pellets of DES and it was estimated that 100-200 $\mu \mathrm{g}$ DES were absorbed per day. Goldenberg et al. (1972) established a dose response relationship for the subcutaneous injection of DES to hypophysectomized rats and found that $1 \mathrm{mg} /$ day for 4 days was the optimal dose to maintain ovarian weight in immature animals. Therefore the $2 \mathrm{mg}$ DES/day for 3 days used in this study is within bounds and stimulated proliferation of medium-sized follicles in the ovaries of hypophysectomized immature (Table 2) and adult rats. The fact that DES was effective in adult rats shows that the ovary of the adult rat still possesses the potential to respond to large doses of oestrogens. To our knowledge, all previous studies with DES or oestradiol have utilized immature rats.

To eliminate the possibility that circulating oestrogens are handled differently in hamsters and rats, we substituted OECP for DES because OECP is converted to oestradiol and the latter compound is routinely measured in our laboratory. The results in Table 1 indicate that concentrations of serum oestradiol are elevated to the same extent in immature rats and hamsters after injection of OECP and yet the hamster ovary still does not respond although the uterus does. This correlates, after oestrogen treatment, with the response of Stage I follicles in the hamster ovary and Stage IV follicles and above in the rat (Table 2). Oestrogen treatment consistently increased the number of antral follicles only in the intact immature rat (Table 2), indicating that interactions with gonadotrophins are essential for the final phases of folliculogenesis. After hypophysectomy of immature rats a few healthy antral follicles were still present 4 days later (Table 2), but this is consistent with previous quantitative studies of follicular development in untreated hypophysectomized rats (Lane \& Greep, 1935; Paesi, 1949).

It might be argued that the failure of the ovary of the Day 23 hamster to respond to oestrogen could be related to the time of its administration and that treatment 2 or 3 weeks before or after Day 26 would dramatically enhance follicular development. Two lines of evidence militate against this 
reasoning: (1) the ovary of the immature hamster from Day 8 to 30 (Greenwald \& Peppler, 1968) or the adult ovary (Greenwald, 1974) never show a preponderance of large preantral and antral follicles comparable to those in immature rats (Table 2); and (2) although the ovary of hypophysectomized adult rats can be stimulated directly by oestrogen, this does not occur in hamsters, even when OECP is instilled into the ovarian bursa.

Receptors for oestradiol are present in the ovary of immature rats 22-28 days old (Saiduddin \& Zassenhaus, 1977). Based on the above observations, we suggest that the ovary of the immature hamster possesses few binding sites for oestrogen whereas they are present in the uterus, albeit in reduced numbers compared to the rat, and that oestrogens do not play a major role in the initiation of growth of large preantral follicles at puberty and in the cyclic hamster.

This research was supported by a grant to G.S.G. from the NIH (HD-00596). Inkyo Kim was supported as a Rockefeller Foundation fellow and Chandrima Shaha was supported as a Ford Foundation postdoctoral fellow.

\section{References}

Bradbury, J.T. (1961) Direct action of estrogen on the ovary of the immature rat. Endocrinology 68, 115-120.

Chiras, D.D. \& Greenwald, G.S. (1978) Effects of steroids and gonadotropins on follicular development in the hypophysectomized hamster. Am. J. Anat. 152, 307320.

Dixon, W.J. (1981) BMDP Statistical Software, pp. 349387. University of California Press, Berkeley.

Exley, D., Johnson, M.W. \& Dean, P.D.G. (1971) Antisera highly specific for $17 \beta$-estradiol. Steroids 18 , 605-620.

Goldenberg, R.L., Vaitukaitis, J.L. \& Ross, G.T. (1972) Estrogen and follicle stimulating hormone interactions on follicle growth in rats. Endocrinology 90 , 1492-1498.

Greenwald, G.S. (1974) Quantitative aspects of follicular development in the untreated and PMS-treated cyclic hamster. Anat. Rec. 178, 139-143.

Greenwald, G.S. \& Peppler, R.D. (1968) Prepubertal and pubertal changes in the hamster ovary. Anat. Rec. 161, 447-458.

Lane, C.E. \& Greep, R.O. (1935) The follicular apparatus of the ovary of the hypophysectomized immature rat and the effects of hypophyseal gonadotropic hormones on it. Anat. Rec. 63, 139-146.

Lukaszewska, J.H. \& Greenwald, G.S. (1970) Progesterone levels in the cyclic and pregnant hamster. Endocrinology 85, 1160-1165.

Moore, P.J. \& Greenwald, G.S. (1974) Effect of hypophysectomy and gonadotropin treatment on follicular development and ovulation in the hamster. $A m . J$. Anat. 139, 37-48.
Nakayama, T., Nakano, R. \& Iwao, M. (1981) Evidence for a role of endogenous estrogen on follicular growth in immature female rats. Endocr. japon. 28, 715-723.

Paesi, F.J.A. (1949) The influence of hypophysectomy and of subsequent treatment with chorionic gonadotrophin on follicles of different size in the ovary of the rat. Acta endocr., Copenh. 3, 89-104.

Pencharz, R.I. (1940) Effect of estrogens and androgens alone and in combination with chorionic gonadotropin on the ovary of the hypophysectomized rat. Science, N.Y. 91, 554-555.

Rao, M.C., Midgley, A.R., Jr \& Richards, J.S. (1978) Hormonal regulation of ovarian cellular proliferation. Cell 14, 71-78.

Richards, J.S. (1975) Estradiol receptor content in rat granulosa cells during follicular development. Modification by estradiol and gonadotropins. Endocrinology 97, 1174-1184.

Saidapur, S. \& Greenwald, G.S. (1978) Peripheral blood and ovarian levels of sex steroids in the cyclic hamster. Biol. Reprod. 18, 401-408.

Saiduddin, S. \& Zassenhaus, H.P. (1977) Estradiol-17 $\beta$ receptors in the immature rat ovary. Steroids $29,197-$ 213.

Terranova, P.F. \& Greenwald, G.S. (1978) Steroid and gonadotropin levels during the luteal follicular shift of the cyclic hamster. Biol. Reprod. 18, 170-175.

Williams, P.C. (1940) Effect of stilboestrol on the ovaries of hypophysectomized rats. Nature, Lond. 145, 388389 .

Received 31 January 1984 